\title{
CHANGES IN ORGANIC CARBON POOL IN AGRICULTURAL SOILS AND ITS DIFFERENT DEVELOPMENT IN INDIVIDUAL AGRO-CLIMATIC REGIONS OF SLOVAKIA
}

\author{
GABRIELA BARANČÍKOVÁ*, JARMILA MAKOVNÍKOVÁ, RASTISLAV SKALSKÝ, \\ ZUZANA TARASOVIČOVÁ, MARTINA NOVÁKOVÁ, JÁN HALÁS, \\ ŠTEFAN KOCO, MONIKA GUTTEKOVÁ
}

Soil Science and Conservation Research Institute, Bratislava

\begin{abstract}
BARANČÍKOVÁ, G. - MAKOVNÍKOVÁ, J - SKALSKÝ, R. - TARASOVIČOVÁ, Z. - NOVÁKOVÁ, M. - HALÁS, J. - KOCO, Š. - GUTTEKOVÁ, M.: Changes in organic carbon pool in agricultural soils and its different development in individual agro-climatic regions of Slovakia. Agriculture (Pol’nohospodárstvo), vol. 59, 2013, no. 1, pp. 9-20.
\end{abstract}

Soil organic carbon (SOC) is one of the basic parameters of soil productivity and quality. Generally soil has potential to sequestrate or release organic carbon depending on land use/management and climatic conditions. The main aim of this article is to show changes in SOC in agricultural land of Slovakia over almost the last 40 years on the basis of modelling data of SOC stock by the RothC model and unequal development of SOC stock on agro-climatic regions of Slovakia. The results received show that average SOC stock [t/ha] in Slovakia is higher on grasslands in comparison to arable land. However, total SOC pool (t) in top of $0.2 \mathrm{~m}$ of soil on the modelling area of agricultural Slovak land shows that a considerable part of SOC stock is located in arable land and is approximately four times greater than on grasslands because the arable land represents about $80 \%$ of the modelling area. In the first modelling period (1970-1994), the SOC stock gradually increased, but in the second modelling period (1995-2007) no significant changes in SOC stock on the arable land were observed. In the southwest part of Slovakia, increasing of SOC stock during all modelling periods was observed; however, in the northeast part a slight increase of SOC stock only in the first modelling period (1970-1994) was found and in the second modelling period (1995-2007) decrease of SOC accumulation was observed. The results of this statistical analysis show significant relationship between carbon input/SOC stock as independent variables and agro-climatic regions as dependent variable.

Key words: agriculture land, soil organic carbon, long-term simulation, RothC model, agro-climatic regions

Soil organic carbon (SOC) is a basic soil parameter determining soil fertility, water holding capacity and susceptibility to land degradation. SOC also takes part in ecological functions and is one of the components of all minimum data sets evaluating soil quality (Brejda et al. 2000). In a global context, the quantity of carbon stored in soils represents the largest store of terrestrial organic carbon (Houghton et al. 2001). In the top $0.2 \mathrm{~m}$ of soil about $615 \mathrm{Gt}$ is stored (Guo \& Gifford 2002). Soil has the potential for organic carbon release or sequestration, depending on land use, land management and climatic conditions. The fourth assessment report of the
Intergovernmental Panel on Climate Change (IPCC AR4) included details of the agricultural mitigation potential (Smith et al. 2007a) through practices such as carbon sequestration by soil management. In present time, it is essential for countries to estimate mitigation potential at a national scale. There are several methods of estimating changes in $\mathrm{SOC}$ at a national scale. The IPCC Guidelines (IPCC 2006) provide a three-tiered approach where the tier 3 is based on dynamic model if the data and model are available.

Models of SOC dynamics are a well-known tool to simulate the response of the soil system to en-

RNDr. Gabriela Barančíková, CSc. (*Corresponding author), Soil Science and Conservation Research Institute Bratislava, working place Prešov, 08001 Prešov, Raymannova 1, Slovak Republic. E-mail: g.barancikova@vupop.sk 
vironmental pedoturbations and are widely used to study changes in SOC stocks (Peltoniemi et al. 2007). Models of SOC dynamics should provide us with an indication about the size of the SOC stock under different soil types, management practices and climate regimes. The main characteristics of the most popular process-oriented SOC turnover models have been discussed frequently in the literature (Viaud et al. 2010). From this review, it has been observed that the CENTURY, RothC and DNDC are the most frequently used models to simulate SOC dynamics spatially. The CENTURY model is a general ecosystem model for C, N, P, S cycling in the soil - plant system. In conditions of Slovakia, this model was used for modelling of SOC stock on one of the representative Slovak cropping farms (So-bocká et al. 2007). Recently, in the Žitný ostrov region the DAISY model (Takáč et al. 2011) was used for simulating the SOC stock. Generally, these models require many specific input parameters, which are difficult to receive for country scale profile. For this reason the RothC model is used for the prediction of SOC stock on agricultural soils in country scale (Coleman \& Jenkinson 2005). RothC26.3 was originally developed and parameterized to model the turnover of organic $\mathrm{C}$ in arable topsoils from the Rothamsted long-term field experiments. Later, it was extended to model the turnover in the grassland and in woodland, and operate in different soils under different climates (Coleman et al. 1997). RothC-26.3 has been tested against long-term experiments in a range of soils and climatic conditions in Western and Central Europe (Coleman et al. 1997; Falloon \& Smith 2002) and more recently in Japan (Shirato \& Yokozawa 2005), Mexico (GonzalesMolina et al. 2011) and India (Bhattacharyya et al. 2011). In present time, the RothC model is used in prognosis of SOC in regional scale (2010) and for the prediction of SOC stock in agricultural soils of Europe, European part of Russia (Smith et al. 2005, 2007b), for Amazon region of Brazil (Cerri et al. 2007) and for country-scale estimation of potential carbon sequestration on Japanese arable soils (Yokozawa et al. 2010). In Slovakia, the RothC model was successfully tested on selected monitoring localities of agricultural soils there (Barančíková 2007), in conditions of Easter Slovak Lowland (Barančíková et al. 2010a), and subsequently was applied for test- ing of modelling of SOC stock on agricultural soils of Slovakia (Barančíková et al. 2010b). Recently, this model was successfully used for simulation of SOC changes in Slovak arable land (Barančíková et al. 2012).

The main aim of this article is to show the development of SOC changes on the agricultural land of Slovakia over almost the last 40 years on the basis modelling data of SOC stock by the RothC model. Other important aspects of this work are:

- to demonstrate relationship between organic carbon input and changes of SOC stock on agriculture soils (arable soils / grasslands) of Slovakia, and

- to determine, on the basis of statistical analysis, correlations between the SOC stock and diverse climatic conditions.

\section{MATERIAL AND METHODS}

\section{Agro-climatic regions}

The agricultural land of Slovakia is divided into 10 agro-climatic regions (Džatko et al. 1989) which take into account different climatic characteristics and the resulting differences in land management, in crop (crop rotation) and cattle (species of livestock) production. Agro-climatic regions 00-02 represent mainly lowlands and hilly lands on the southwest part of Slovakia with typical soil types such as Chernozem, Fluvisols and Luvisols. Agroclimatic regions $03-06$ are on lowlands and hilly lands of Košice and South Slovakia basins with representative soil types such as Luvisols, Stagnosols, Cambisols and Fluvisols. Agro-climatic region 07 is located on the foothills and basins, and the $08-10$ agro-climatic regions are the mountain area with Cambisols, Stagnosols and Leptosols soil types (WRB 2006).

\section{RothC model}

RothC-26.3 is a model for the turnover of organic carbon in non-waterlogged top soils that allows the effects of soil types, temperature, moisture content and plant cover on the turnover process. The RothC-26.3 model splits SOC into four active compartments and a small amount of inert organic matter (IOM) (Coleman et al. 1997). Modelling of the 
SOC stock with RothC-26.3 model requires three types of data:

a) Climatic data - monthly rainfall $[\mathrm{mm}]$, monthly evapotranspiration $[\mathrm{mm}]$, average monthly mean air temperature $\left[{ }^{\circ} \mathrm{C}\right]$;

b) Soil data - clay content [\%], inert organic carbon (IOM), initial soil organic carbon (SOC) stock [ $\mathrm{t} \mathrm{C} / \mathrm{ha}$ ], depth of the soil layer considered [ $\mathrm{cm}]$;

c) Land use and land management data - soil cover, monthly input of plant residues [ $\mathrm{t} \mathrm{C} / \mathrm{ha}$ ], monthly input of farmyard manure (FYM) [t C/ha].

Further details of the RothC model and the model itself, can be obtained from publication of Barančíková et al. (2011) or from the GCTE SOMNET website (http://www.rothamsted.bbsrc.ac.uk/aen/somnet/).

\section{Input data}

The agricultural land of Slovakia was divided into regular spatial simulation units (SimU). Each SimU was designed so that it represented one cell of $10 \mathrm{~km}$ resolution regular grid.

Point measurements $(n=70)$ of daily mean temperature $\left[{ }^{\circ} \mathrm{C}\right]$, potential evapotranspiration $[\mathrm{mm}]$, and rainfall $[\mathrm{mm}]$ were interpolated to the $10 \mathrm{~km}$ spatial resolution grid using interpolation algorithm based on weather station similarity to unknown interpolated location (Nováková 2007). The monthly rainfall $(\mathrm{mm})$ and average monthly mean air temperature $\left[{ }^{\circ} \mathrm{C}\right]$ and evapotranspiration were calculated based on interpolated daily data.

The mean topsoil values of the initial SOC stock [ $\mathrm{t} / \mathrm{ha}$ ] and clay content [\%] in the $0.2 \mathrm{~m}$ topsoil layer were calculated for each SimU using soil profile data coming from the national soil profile database which includes soil data of 17,741 soil probes (Skalský \& Balkovič 2002). The soil profiles were stratified according to topsoil SOC content and topsoil texture and only the most frequent soil profile class was used for calculation of the initial SimU SOC stock. NUTS4 (nomenclature territorial units for statistic on level district) level agricultural statistics on crop harvesting areas, crop yields and manure application rates were used as a source of soil management data. Regarding politically and socio-economically driven land use changes in Slovakia in early 1990s, land use data were interpreted separately for the 1970-1994 and 1995-2007 periods. Crop harvesting areas were analyzed to get regionally representative crop shares for estimation of organic carbon inputs from crop residues.

The calculated values of the organic carbon input of plant residues according to the published carbon conversion coefficients (Bielek \& Jurčová 2010) of individual plant residues and crops yields and default RothC model settings were used for the estimation of SimU-related monthly carbon of plant residues' inputs to soil [t/ha]. FYM consumption statistic served as the source to analyze the regionally specific rates of manure application [ $\mathrm{t} / \mathrm{ha}$ ] on arable land. Published data of carbon conversion coefficients (Bielek \& Jurčová 2010) and FYM manure dose were used to estimate the SimU-related monthly application rate of carbon farmyard manure [t/ha] for the cropland. For calculation of carbon input from plant residues on grasslands, carbon conversion coefficient for temporary meadows in 4th year (Bielek \& Jurčová 2010) was applied and also as carbon source the excreta of grazing animals was taken into account (Tarasovičová \& Barančíková 2011).

More detailed information about delimitation of agricultural land and about input data can be found in the publication of Tarasovičová et al. (2009) and Barančíková et al. (2011).

\section{Statistical evaluation}

Basic statistical parameters between SOC stock and organic carbon inputs were processed. Evaluation of statistical results proceeded in STATGRAPHICs Centurion XVI.

\section{RESULTS AND DISCUSSION}

\section{Development of SOC stock on arable land and per-} manent grasslands

As can be seen in Figure 1, the average value of SOC stock on grasslands is higher in comparison to arable soils. This is consistent with the literature data that indicate that the difference of SOC pool between arable land and grasslands may represent up to $60 \%$ (Guo \& Gifford 2002). High intensity of SOC mineralization and thus reduction of SOC stock on arable land is caused primarily by the deep ploughing (Chukov 2000). 
According to the modelling data, the SOC stock on agriculture soils until 1994 gradually increased and higher growth was recorded on permanent grasslands (Figure 1). After 1994, the SOC stock on grasslands started to slightly decrease, while on arable soil is maintained at the reached level (Figure 1).

As mentioned in the introduction, SOC stock on agricultural soils is mainly influenced by organic carbon inputs from plant residues and manure (Schulp \& Verbung 2009; van Wesemael et al. 2010). According to the data in Table 1, it is clear that $\mathrm{C}$ input from crop residues on arable soils during modelling period continuously increased, but the carbon input from farmyard manure significantly declined. In the case of grasslands, a sharp decline of carbon input from grazing of livestock and also slight decrease of $\mathrm{C}$ input from plant residues (Table 2) can be the reason of higher decline of SOC stock on grasslands in comparison to arable soils.

Figure 1 shows that decline of SOC stock in agricultural soils of Slovakia after 1994 is evident. If carbon inputs are divided into two periods, 19701994, 1995-2007, it is clear that the C inputs in the first period are higher than that in the second period primarily on permanent grasslands (Tables 1 and 2). Lower inputs of organic carbon into the soil after 1994 has resulted from the changes in the methods of Slovak agriculture since the early 90 s, and may have had adversely affected the SOC stock in this period.

Besides, the significant changes observed in carbon inputs, slightly decreasing the SOC stock on grasslands and maintaining SOC stock at the reached level on arable land since 1994, may be due to the increasing of average annual temperature recorded in Slovakia (Table 3). In the first two decades (1970-1990), the average temperatures in Slovakia were almost identical; however, in the last two decades a significant warming in Slovakia has been observed, which characterizes the increase in annual temperature in the last two decades of the modelling period (Table 3). The decline of SOC stock has been due to the rising temperature, mentioned by Smith et al. (2005), on agricultural land of 15 EU countries and arable land in European Russia and Ukraine (Smith et al. 2007). Xu et al. (2011) reported that in

$$
\mathrm{T} \text { a }
$$

Average year temperature $(\mathrm{T})$ in individual decades

\begin{tabular}{|c|c|}
\hline Time-interval & Average year T $\left[{ }^{\circ} \mathrm{C}\right]$ \\
\hline $1970-1979$ & 8.38 \\
$1980-1989$ & 8.21 \\
$1990-1999$ & 8.77 \\
$2000-2007$ & 9.12 \\
\hline
\end{tabular}
during modelling period (1970-2007) on arable land

\begin{tabular}{|c|c|c|c|}
\hline Time-interval & C CR [t/ha] & C FYM [t/ha] & $\begin{array}{c}\text { C CR + C FYM } \\
\text { [t/ha/year] }\end{array}$ \\
\hline 1970 & - & - & 1.16 \\
$1970-1979$ & 1.10 & 0.93 & 2.03 \\
$1980-1989$ & 1.07 & 0.93 & 2.00 \\
$1990-1999$ & 1.18 & 0.45 & 1.63 \\
$2000-2007$ & 1.22 & 0.36 & 1.58 \\
$1970-1994$ & 1.16 & 0.56 & 1.72 \\
$1995-2007$ & 1.33 & 0.36 & 1.69 \\
$1970-2007$ & 1.14 & 0.47 & 1.61 \\
\hline
\end{tabular}


response to higher temperature, RothC predicted a decrease in the SOC stock of Irish grasslands. Also our results (Barančíková et al. 2011) show decreasing of SOC stock prediction by RothC model as response to higher temperature.
The total stock of SOC in the whole area of agricultural soils of Slovakia in the top $0.2 \mathrm{~m}$ of soil in present time is more than 60 million tons (Figure 2). However, it should be noted, that the territory in which the modelling of SOC stock was realized

\section{T}

Average year $\mathrm{C}$ input of crop residues $(\mathrm{C} \mathrm{CR})$ and $\mathrm{C}$ of excreta of grazing animals (C EGA) during modelling period 1970-2007 on grasslands

\begin{tabular}{|c|c|c|c|}
\hline Time-interval & C CR [t/ha] & C EGA [t/ha] & $\begin{array}{c}\text { C CR }+ \text { C EGA } \\
\text { [t/ha/year] }\end{array}$ \\
\hline 1970 & - & - & 1.57 \\
$1970-1979$ & 1.99 & 0.62 & 2.61 \\
$1980-1989$ & 1.99 & 0.68 & 2.67 \\
$1990-1999$ & 1.66 & 0.42 & 2.08 \\
$2000-2007$ & 1.51 & 0.26 & 2.60 \\
$1970-1994$ & 2.00 & 0.60 & 1.74 \\
$1995-2007$ & 1.45 & 0.29 & 1.31 \\
\hline
\end{tabular}

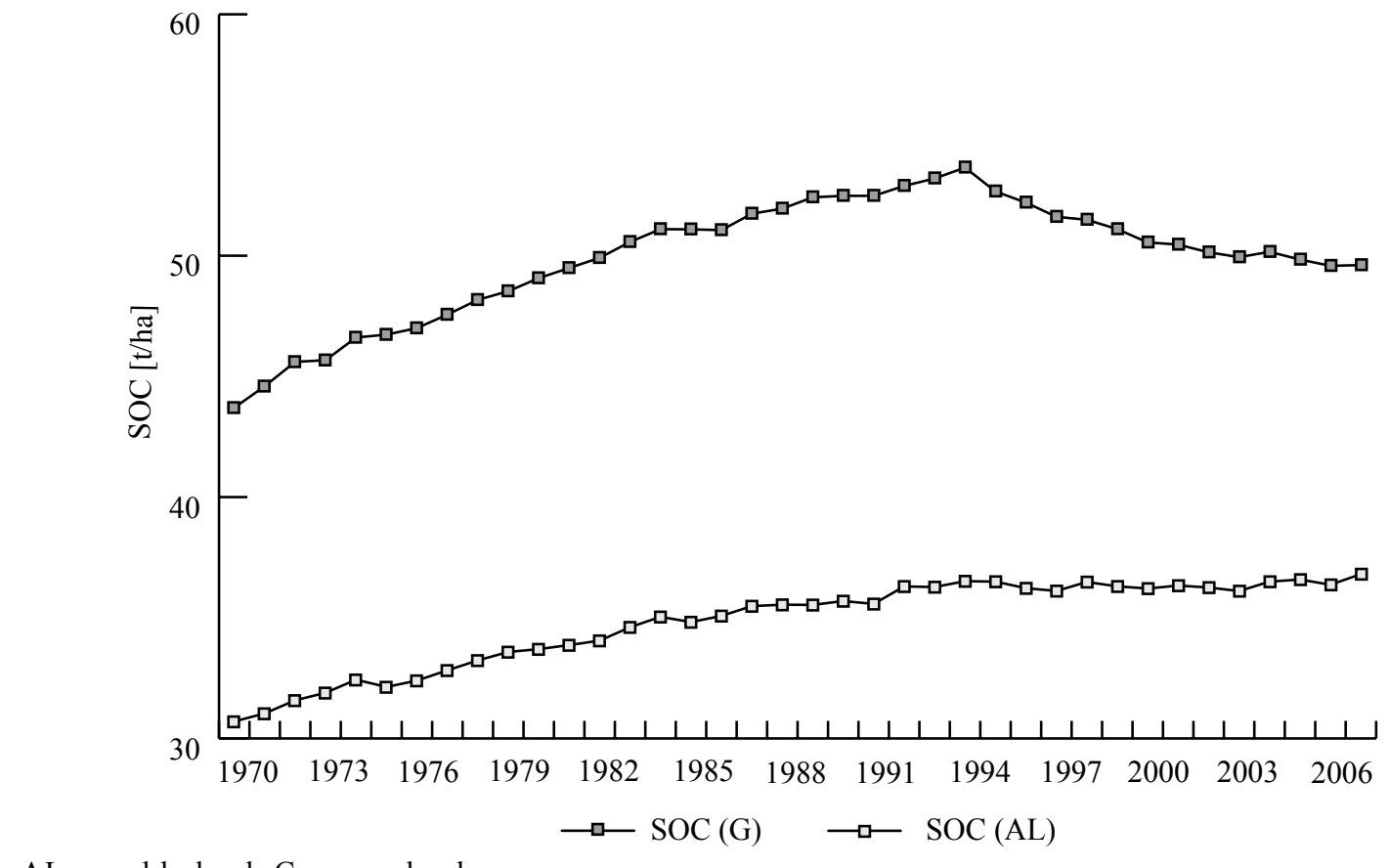

$\mathrm{AL}$ - arable land, G - grassland

Figure 1. Development of average values of simulated SOC stock [t/ha] during modelling period on the arable land $(\mathrm{AL})$ and grassland $(\mathrm{G})$ of Slovakia 
represents about $85 \%$ of the total agricultural area according to the latest version of LPIS (Land Parcel Identification System) (year 2011). This is the consequence of that modelling of SOC stock in $10 \times 10 \mathrm{~km}$ grids following the subsequent criteria. As the primary criterion, for the selection of territorial units suitable for modelling, a parameter of $25 \%$ of agricultural land of the total area of cell was chosen. Another criterion was at least $25 \%$ of arable soils / grasslands from such grid which contain more than $25 \%$ of agricultural land. The final criterion for modelling arable land/grasslands was $40 \%$ of the relevant category of land type in the cell. From this reason, the modelled area of the agricultural land is less than the real area of agricultural land according to the latest version of the LPIS. Modelling of SOC stock included 271 grids of arable land and 96 grids of pasture.

As can be seen from Figure 2, a considerable part of SOC stock is located in arable land and is approximately 4 times greater than on grasslands, despite the fact that average stock of SOC in $t / h a$ on grassland is higher than on arable soils (Figure 1). This is because the arable land of the modelling area is significantly larger as grasslands and represents about $80 \%$ of the Slovak agricultural soils.

Changes of SOC stock in different climatic conditions

Based on division of the territory of Slovakia on agro-climatic regions, it is clear that the highest SOC stocks in top of $0.2 \mathrm{~m}$ of soil in $\mathrm{t} / \mathrm{ha}$ are in the agro-climatic region 00 on Danubian lowland (Figure 3) and agro-climatic region 10 on the mountain soils of north and central Slovakia.

As can be seen from Figure 4, in agro-climatic regions $00-06$ on southwest and southeast part of Slovakia evident increasing of SOC stock until 1994 was observed. In the mountain area of Flysh zone, Tatra and Orava Basin and Orava highland there are mainly Cambisols and Stagnosols increasing of SOC stock minimal (Figure 4). On the basis of different developments of SOC stock on arable land of agro-climatic regions, these regions can be divided into three groups.

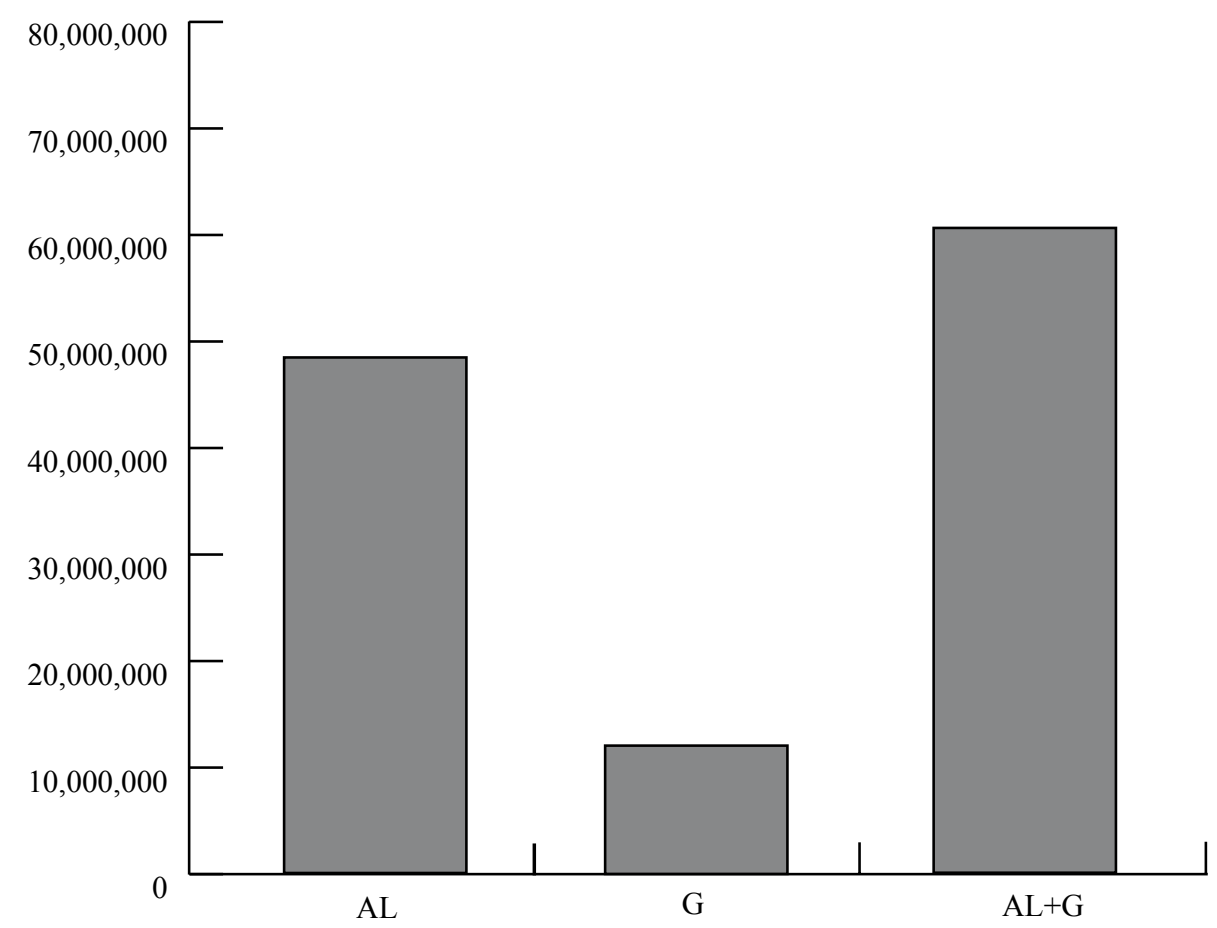

Figure 2. SOC inventories (t) on arable land (AL) and grasslands (G) on modelled territory in 2007 
Changes of SOC stock in arable land

In the first group are arable lands of agro-climatic regions 00-02 on Danube and Zahorie lowlands. This group's characteristics influenced the increasing of SOC stock during the entire modelling period (1970-2007); however, in the first term (1970-1994), increasing of SOC stock is higher than in the second modelling term (19952007) (Figure 3).

The second group includes arable lands of agro-climatic regions 04-06. This group's characteristics influenced the increasing of SOC stock until 1994 and from this period the SOC stock has remained the same (Figure 3).

In the third group are arable lands of agro-climatic regions 03, 07-10 localized mainly on Easter Slovak Lowland (03) and northeast part of Slovakia on Flysh zone of Ondava Highlands and Čergov and on north part of Slovakia on Tatra and Orava Basins and Orava Highlands. In agro-climatic regions $07-10$, the lowest increasing of SOC stock until
1994 was determined and in the following period a decrease of SOC stock was found (Figure 3).

Different development of SOC stock in individual agro-climatic regions can be primarily due to different carbon inputs, because in agro-climatic region 10 the carbon inputs represent only $66 \%$ of $\mathrm{C}$ inputs of agro-climatic region 00 (Table 4). Increasing of SOC stock until 1994 on all regions and following stagnation or decreasing can be due to different $\mathrm{C}$ inputs (Table 4). Another reason can be more favourable climate and pedological conditions in region 00 in comparison to region 10 .

\section{Changes of SOC stock in grasslands}

Development of SOC stock on grasslands are not modelled in agro-climatic regions $00-02$ and 04 because the area of grasslands is low and represents less than $40 \%$ of agricultural land.

As can be seen from Figure 5 the highest SOC stock on grasslands is on Fluvisols and Luvisols of agro-climatic regions 03 and on mountain meadows of region 10. Likewise, on

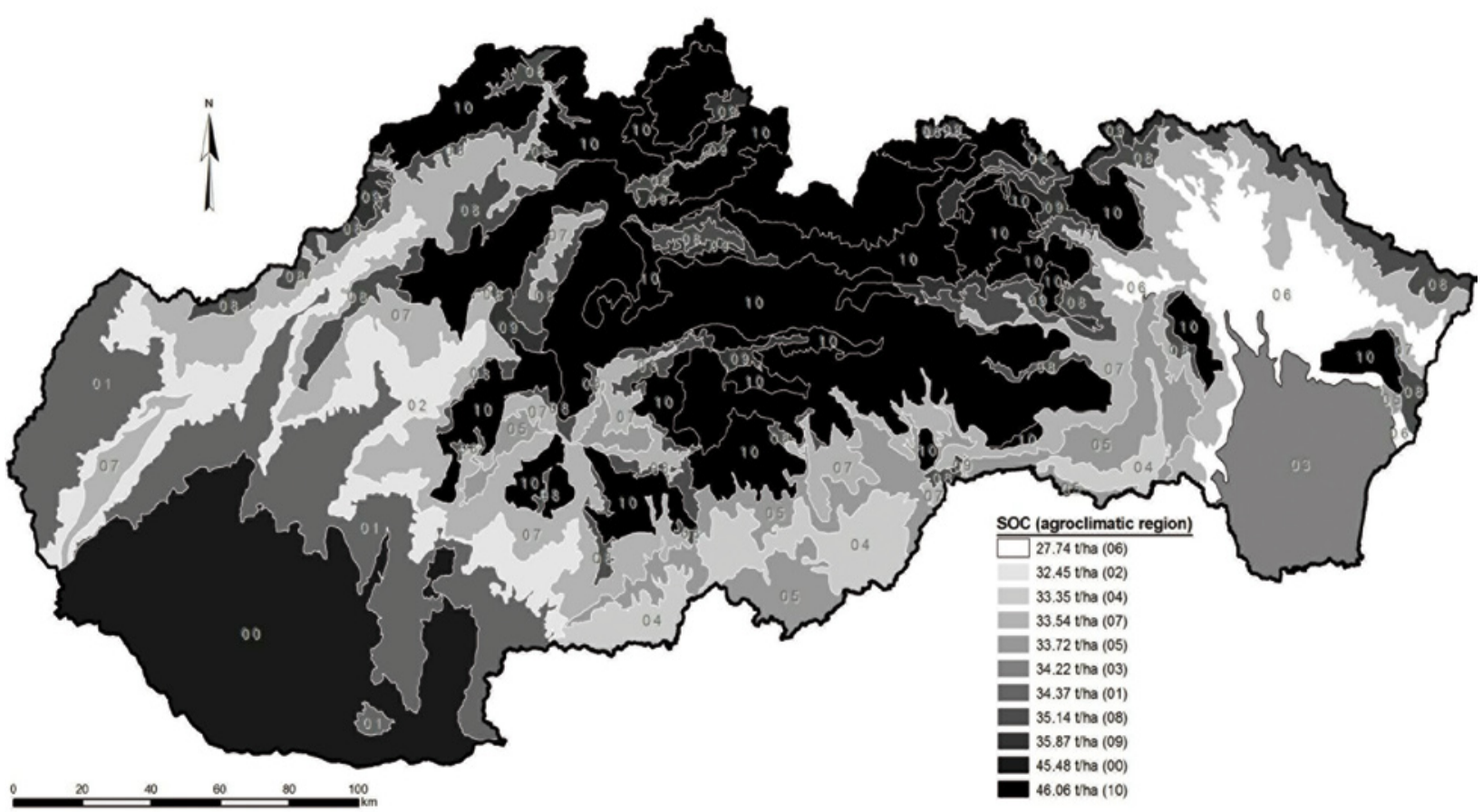

Figure 3. SOC stock in 2007 on the agro-climatic regions of Slovakia 
arable land until 1994 slight increase of SOC SOC stock after 1994 can be due to substanon grasslands was determined and after this pe- tial lower carbon inputs after 1994 (Table 4). riod the SOC stock decreased. Decreasing of

$$
\mathrm{T} \text { a }
$$

Average organic carbon (C) input [t/ha/year] on arable land (AL) and grasslands (G) according to agro-climatic regions in the first (1970-1994) and second (1995-2007) modelling period

\begin{tabular}{|c|c|c|c|c|}
\hline \multirow{2}{*}{ Agro-climate regions } & $\begin{array}{c}\text { Input C } \\
1970-1994 \mathrm{AL}\end{array}$ & $\begin{array}{c}\text { Input C } \\
1995-200 \mathrm{AL}\end{array}$ & $\begin{array}{c}\text { Input C } \\
1970-1994 \mathrm{G}\end{array}$ & $\begin{array}{c}\text { Input C } \\
1995-2007 \mathrm{G}\end{array}$ \\
\hline 00 & 2.024 & 2.160 & - & - \\
01 & 1.940 & 2.005 & - & - \\
02 & 1.778 & 1.885 & - & - \\
03 & 1.667 & 1.671 & 3.315 & 1.642 \\
04 & 1.799 & 1.698 & - & 1.425 \\
05 & 1.628 & 1.589 & 2.816 & 1.678 \\
06 & 1.429 & 1.396 & 2.479 & 1.672 \\
08 & 1.487 & 1.375 & 2.613 & 1.943 \\
09 & 1.474 & 1.375 & 2.582 & 1.905 \\
\hline
\end{tabular}

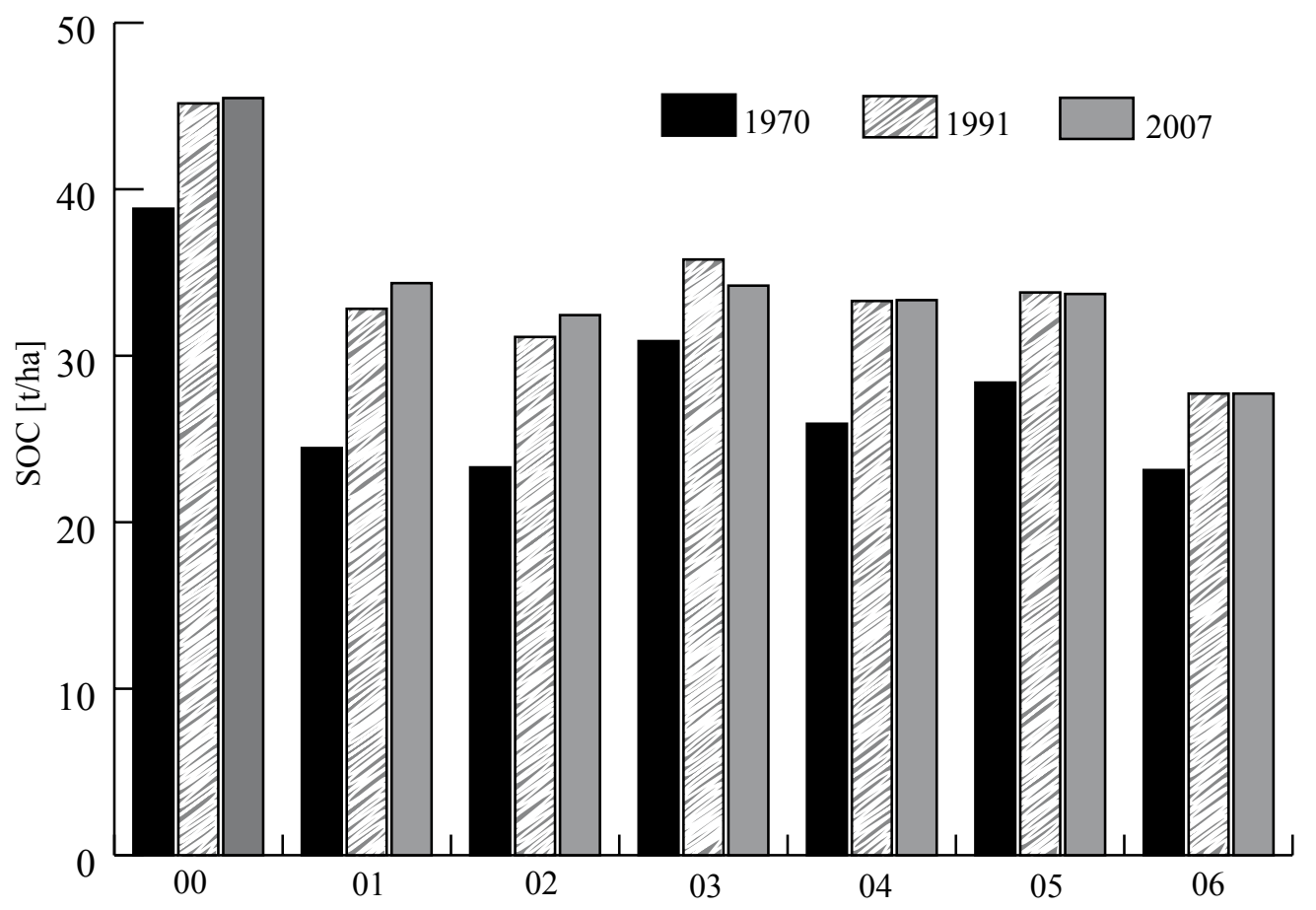

Figure 4. Development of SOC stock [t/ha] according to agro-climatic regions on arable land 
The relationship between agro-climatic regions and SOC model values

As the SOC stock is also influenced by climatic parameters, particularly temperature and moisture, we are trying to analyze the relationship between the SOC stock and agro-climatic regions of Slovakia.

Statistical analysis of the relationship between the modelled values of SOC stock (respectively one of the most important input parameters of the model RothC - carbon inputs) and agro-climatic regions was performed in the STRATGRAPHICs Centurion XVI. The statistical dependence between two quantitative variables was evaluated by Pearson parametric correlation coefficients that are not sensitive to outlying values (Table 5).

Pearson correlation coefficients indicate a linear relation between SOC stock in the year 1970, 1994 and 2007 and one of the most important input parameters of the model RothC - carbon inputs in the period 1970-2007. In the case of grasslands, the

$\mathrm{T}$ a

Pearson correlation coefficients

\begin{tabular}{|c|c|c|c|c|}
\hline \multirow{3}{*}{ Agro-climatic region } & \multicolumn{3}{|c|}{ Pearson correlation coefficients } & Carbon input [t/ha] \\
\cline { 2 - 5 } & \multicolumn{3}{|c|}{ SOC stock [t/ha] } & 2007 year \\
\cline { 2 - 5 } & 1970 year & 1994 year & $0.27^{+}$ & $0.35^{+}$ \\
\hline Grasslands & $0.26^{+}$ & $0.22^{+}$ & $-0.26^{+}$ & $-0.52^{+}$ \\
Arable land & 0.01 & 0.10 & & \\
\hline
\end{tabular}

${ }^{+} P<0.05$

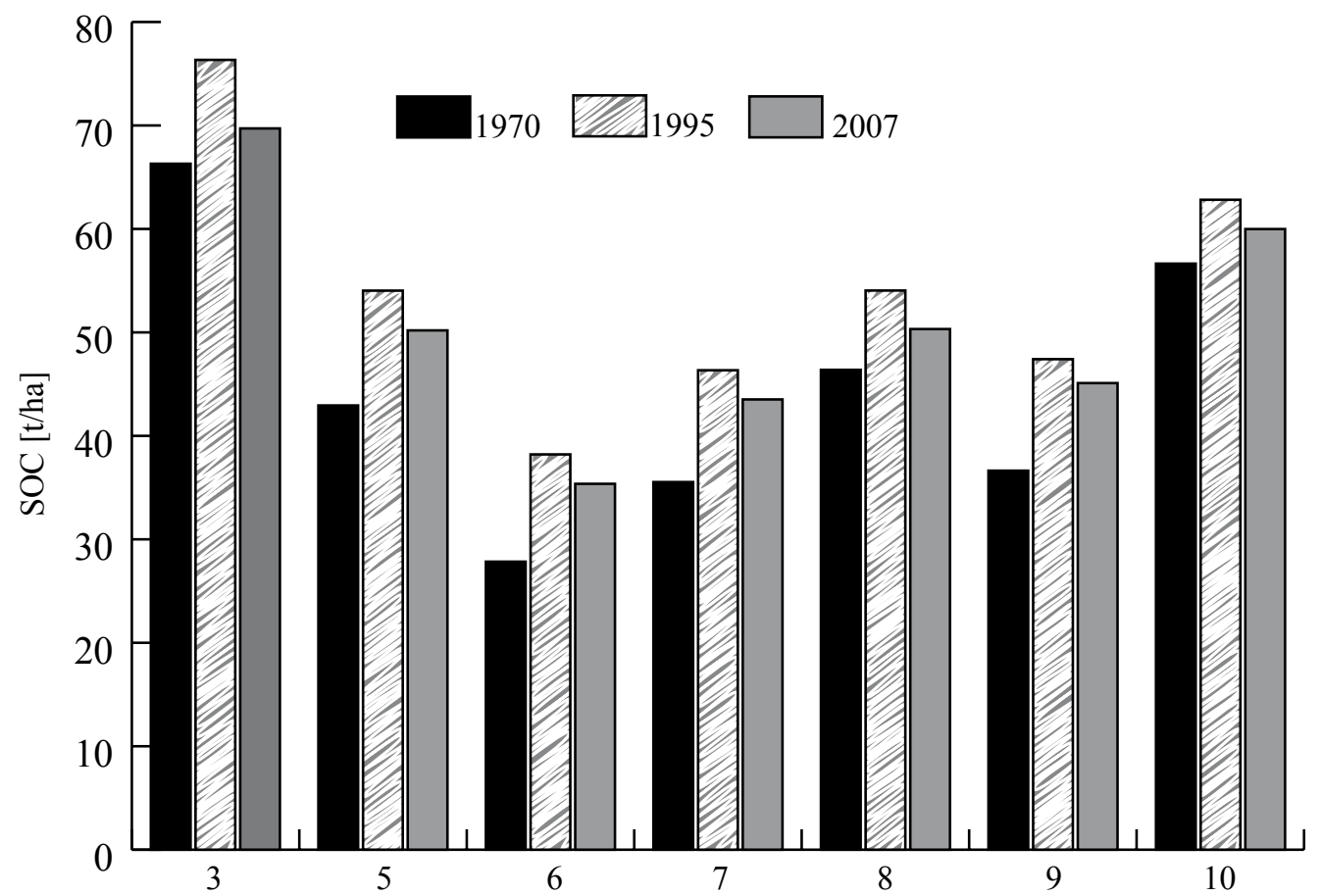

Figure 5. Development of SOC stock [t/ha] according to agro-climatic regions on permanent grasslands 
positive correlation between SOC stock and carbon input as independent variables and agro-climatic regions as dependent variable indicates increasing of SOC stock in agro-climatic regions marked by a higher number. Pearson correlation coefficients between SOC stocks in 1970, 1994 and 2007, and agroclimatic regions are lower in the case of arable land than in the case of permanent grasslands. A higher degree of dependence was determined only for one of the most important input data of the model RothC - carbon inputs in the period 1970-2007. Contrary to grasslands' negative dependences between SOC stock in 2007 and carbon inputs in the period 1970 to 2007 were found.

\section{CONCLUSIONS}

Results receiving from modelling of SOC stock on agricultural land of Slovakia show increasing of SOC stock in the first modelling period (1970 1994) on arable land and permanent grasslands. In the second modelling period (1994-2007) no significant changes in SOC stock on agricultural Slovak land was observed.

However, the changes in development of SOC stock are not equal on all agro-climatic regions of Slovakia. On arable land of Dunubian and $\mathrm{Za}$ horie lowlands during the entire modelling period (1970-2007), increase of SOC stock was observed. But on north-eastern Slovakia on Flysh region of Ondava Highlands and on Tatra and Orava basins, low increasing of SOC stock only until 1994 was found. In the second modelling period (1995-2007), decreasing of SOC stock on arable land of north-eastern Slovakia was observed. The results of statistical analysis show significant relationship between the most important input parameter of the model RothC - carbon inputs in the period 1995-2007 and agro-climatic regions.

Development of SOC stock on permanent grasslands of all agro-climatic regions showed equal trend - gradually increasing of SOC stock until 1994 and subsequent decline. Results of statistical analysis on grasslands indicate the positive correlation between SOC stock, and carbon input as independent variables and agro-climatic regions as dependent var- iable indicate increasing of SOC stock in agroclimatic regions.

The obtained results show that modelling of SOC stock can be an effective way of estimating changes in SOC and can be used in the prediction of SOC stock at a national scale. It can be concluded that the system presented in this study, linking the RothC model and soil/climate/management spatial data, can be useful to estimate the potential changes of SOC stock on Slovak agricultural land and its response to human driven changes in land use within different climate and other natural conditions.

Acknowledgements. This work was supported by the Slovak Research and Development Agency under contract nos. APVV-0333-06 and APVV0243-11.

\section{REFERENCES}

BARANČÍKOVÁ, G. 2007. Validácia modelu RothC na vybraných monitorovacích lokalitách [Validation of RothC model on selected soil monitoring localities]. In Vedecké práce Výskumného ústavu pôdoznalectva a ochrany pôdy, vol. 29, Brati-slava : VÚPOP, pp. 9-22. ISBN 978-80-89128-40-2

BARANČÍKOVÁ, G. - ŠOLTÝSOVÁ, B. - KOCO, Š. 2010a. Prediction of soil organic carbon stock in conditions of Easter Slovak Lowland. In Agriculture (Pol'nohospodárstvo), vol. 56, 2010, no. 2, pp. $35-45$.

BARANČÍKOVÁ, G. - HALÁS, J. - GUTTEKOVÁ, M. MAKOVNÍKOVÁ, J. - NOVÁKOVÁ, M. - SKALSKÝ, R. - TARASOVIČOVÁ, Z. 2010b. Application of RothC model to predict soil organic carbon stock on agricultural soils of Slovakia. In Soil \& Water Research, vol. 5, 2010, no. 1, pp. 1-9.

BARANČÍKOVÁ G. - GUTTEKOVÁ, M. - HALAS, J. KOCO, Š. - MAKOVNÍKOVÁ, J. - NOVÁKOVÁ, M. - SKALSKÝ, R. - TARASOVIČOVÁ, Z. - VILČEK, J. 2011. Pôdny organický uhlik v polnohospodárskej krajine - modelovanie zmien v priestore a čase [Soil organic carbon in agricultural land - modelling of changes in space and time]. Bratislava : Výskumný ústav pôdoznalectva a ochrany pôdy, 2011. 85 pp. ISBN 978-80-89128-86-0

BARANČÍKOVÁ, G. - MAKOVNÍKOVÁ, J. - SKALSKÝ, R. - TARASOVIČOVÁ, Z. - NOVÁKOVÁ, M. HALÁS, J. - GUTTEKOVÁ, M. - KOCO, Š. 2012. Environmental aspects of soil organic carbon stock changes in cropland of Slovakia. In Soil \& Water Research, vol. 7, 2012, no. 2, pp. 45-51.

BHATACHARYYA, T. - PAL, D.K. - DESHMUKH, A.S. - DESHMUKH, R.R. - RAY, S.K. - CANDRAN, P. 
- MANDAL, C. - TELPANDE, B. - NIMJE, A.M. TIWARY, P. 2011. Evaluation of RothC model using four long term fertilizer experiments in black soils, India. In Agriculture, Ecosystem \& Environment, vol. 144, 2011, no. 1, pp. 222-234.

BIELEK, P. - JURČOVÁ, O. 2010. Metodika bilancie pôdnej organickej hmoty a stanovenia potreby organického hnojenia polnohospodárskych pôd [Methodology of soil organic matter balance and determination the need for organic fertilization of agricultural soils]. Brati-slava : Výskumný ústav pôdoznalectva a ochrany pôdy, 2010. 145 pp. ISBN 978-80-89128-80-8

BREJDA, J.J.-MOORTMAN, T.B.-KARLEN, D.L.-DAO, T.H. 2000. Identification of regional soil quality factors and Indicators: I. Central and Southern High Plains. In Soil Science Society of America Journal, vol. 64, 2000, pp. 2115-2124.

CERRI, C.E.P. - EASTER, M. - PAUSTIAN, K. - KILLIAN, K. - COLEMAN, K. - BERNOUX, M. - FALLOON, P. - POWLSON, D.S. - BATJES, N.H. - MILNE, E. - CERRI, C.C. 2007. Predicted soil organic carbon stocks and changes in the Brazilian Amazon between 2000 and 2030. In Agriculture, Ecosystems \& Environment, vol. 122, 2007, pp. 58-72.

COLEMAN, K. - JENKINSON, D.S. - CROCKER, G.J. GRACE, P.R. - KLIR, J. - KORSCHENS, M. - POULTON, P.R. - RICHTER, D.D. 1997. Simulating trends in soil organic carbon in long-term experiments using RothC-26.3. In Geoderma, vol. 81, 1997, no. 1-2, pp. 29-44.

COLEMAN, K. - JENKINSON, D.S. 2005. ROTHC-26.3 A model for the turnover of carbon in soil. Model description and windows users guide, November 1999 issue (modified April, 2005), 45 pp. Available on http://www. rothamsted.bbsrc.ac.uk/aen/carbon/mod26_3_win.pdf

DŽATKO, A. - MAŠÁT, K. - CAMBEL, B. 1989. Agroklimatické regióny SR [Agro-climatic regions of Slovakia]. Záverečná správa VCPÚ-ÚPVR, Bratislava, 123 pp.

FALLOON, P. - SMITH, P. 2002. Simulating SOC changes in long-term experiments with RothC and CENTURY: model evaluation for a regional scale application. In Soil Use and Management, vol. 18, 2002, no. 2, pp. 101-111. DOI: $10.1111 / \mathrm{j} .1475-2743.2002 . t b 00227 . x$

GONZALES-MOLINA, L. - ETCHEVERS-BARRA, J.D. - PAZ-PELLAT, F. - DIAZ-SOLIS, H. - FUENTESPONCE, M.H. - COVALEDA-OCON, S. - PANDOMORENO, M. 2011. Performance of the RothC-26.3 model in short-term experiments in Mexican sites and systems. In The Journal of Agricultural Science, vol. 149, 2011, no. 4, pp. 415-425.

GUO, L.B. - GIFFORD, R.M. 2002. Soil carbon stocks and land use change: a meta analysis. In Global Change Biology, vol. 8, 2002, pp. 345-360.

HOUGHTON, J.T. - DING, Y. - GRIGGS, D.J. - NOGUER, M. - VAN DEN LINDEN, P.J. - DAI, X. - MASKELL, K. - JOHNSON, C.A. (eds.). 2001. Climate Changes 2001: The scientific basis. New York: Cambridge University Press. Intergovermental Panel on Climate Change.

CHUKOV, S.N. 2000. Study by ${ }^{13} \mathrm{C}-$ NMR spectroscopy of humus acids molecular parameters in anthropogeni- cally disturbed soils. In Proceedings of 10th International Meeting of the IHSS. Toulouse : Progep, 2000, pp. 81-84.

IPCC, 2006. National Greenhouse Gas Inventory Guidelines. vol. 4, Chapter 5: Cropland. Institute of Global Environemntal Strategies (IGES), Kanagawa, 66 p.

IUSS Working Group WRB. 2006. World reference base for soil resources. 2006. World Soil Resources Reports No. 103, Roma : FAO, pp. 145.

NOVÁKOVÁ, M. 2007. Interpolácia meteorologických údajov pre potreby monitoringu stavu vývoja a odhadu úrod pol'nohospodárskych plodín [Weather interpolation as a baseline for crop growth monitoring and crop yield forecasting]. In Vedecké práce Výskumného ústavu pôdoznalectva a ochrany pôdy, vol. 29. Bratislava : VÚPOP, 2007. pp. 95-105, ISBN 978-80-89128-40-2

PELTONIENI, M. - THURING, E. - OGLE, L. - PALOSUO, T. - SCHRUMP, M. - WUTZLER, T. - BUTTERBACH-BAHL, K. - CHERTOV, O. - KOMAROV, A. - MIKHAILOV, A. - GÄRDENES, A. - PERRY, C. - LISKI, J. - SMITH, P. - MÄKUPÄÄ, R. 2007. Models in country scale carbon accounting of forest soils. In Silva Fennica, vol. 41, 2007, pp. 575-602.

SHIROTO, Y. - YOKOZAWA, M. 2005. Applying the Rothamsted Carbon Model for long-term experiments on Japanese paddy soils and modifying it by simple tunning of the decomposition rate. In Soil Science and Plant Nutrition, vol. 51, 2005, pp. 405-415.

SCHULP, C.J.E. - VERBUNG, P.H. 2009. Effect of land use history and site factors on spatial variation of soil organic carbon across a physiographic region. In Agriculture, Ecosystems and Environment, vol. 133, 2009, pp 86-97.

SKALSKÝ, R. - BALKOVIČ, J. 2002. Digital database of selected soil profiles of complex soil survey of Slovakia (KPP-DB). In Vedecké práce Výskumného ústavu pôdoznalectva a ochrany pôdy Vedecké práce, vol. 25, Bratislava : VÚPOP, 2002, pp. 129-140, ISBN 8089128-07-6

SMITH, J. - SMITH, P. - WATTENBACH, M. - ZAEHLE, S. - HIEDERER, R. - JONES, R.J.A. - MONTANARELLA, L. - ROUNSEVELL, M. - REGINSTER, I. - EWERT, F. 2005. Projected changes in mineral soil carbon of European croplands and grasslands, 19902080. In Global Change Biology, vol. 11, 2005, no. 12, pp. 2141-2152. DOI: 10.1111/j.1365-2486.2005.001075.x

SMITH, P. - MARTINO, D. - CAI, Z. - GWARY, D. JANZEN, H. - KUMAR, P. - MCCARL, B. - OGLE, S. - O'MARA, F. - RICE, C. - SCHOLES, B. - SIROTENKO, O. 2007a. Chapter 8: Agriculture. In METZ, B. - DAVIDSON, O.R. - BOSCH, P.R. - DAVE, R. - MEYER, L.A. (eds.). Climate Change 2007: Mitigation. Contribution of Working Group III to the Fourth Assessment report of the Intergovermental Panel on Climate Change. Cambridge, New York.

SMITH, P. - ANDREN,O. - BRUSSAARD, L. - SMITH, J. - SMITH, P. - WATTENBACH, M. - GOTTSCHALK, P. - ROMANENKOV, V.A. - ŠEVCOVA, L.K. - SIROTENKO, O.D. - RUKHOVIČ, D.I. - KOROLEVA, P.V. - ROMANENKO, I.A. - LISOVOJ, N.V. 2007b. Projected changes in the organic carbon stocks of crop- 
land mineral soils of European Russia and the Ukraine 1990-2070. In Global Change Biology, vol. 3, 2007, pp. $342-354$.

SOBOCKÁ, J. - BALKOVIČ, J. - LAPIN, M. 2007. A CENTURY 5 Model using for estimation of soil organic matter behaviour at predicted climate change. In Soil \& Water Research, vol. 2, 2007, pp. 25-34.

TAKÁČ, K. - ŠIŠKA, B. - PÍŠ, V. 2011. Evaluation of adaptive measures to reduce climate change impact on soil organic carbon stock in Žitný ostrov region. In Agriculture (Pol'nohospodárstvo), vol. 57, 2011, no. 3, pp. 85-95. DOI: 10.2478/v10207-011-0009-9

TARASOVIČOVÁ, Z. - NOVÁKOVÁ, M. - SKALSKÝ, R. - BALKOVIČ, J. 2009. Geografická databáza vstupov o počasí, pôde, využívaní krajiny pre model RothC [Geographical database of RothC model inputs on weather, soil and land use]. In Vedecké práce Výskumného ústavu pôdoznalectva a ochrany pôdy, vol. 31, Bratislava: VÚPOP, 2009, pp. 201-210. ISBN 978-80-89128-59-4

TARASOVIČOVÁ, Z. - BARANČÍKOVÁ, G. 2011. Nový prístup pri tvorbe vstupov uhlíka trvalých trávnych porastov Slovenska pre model RothC [New approach of carbon inputs preparation of Slovakia grassland for RothC model]. In Vedecké práce Výskumného ústavu pôdoznalectva a ochrany pôdy, vol. 33, Bratislava : VÚPOP, pp. 184-193. ISBN 978-80-89128-59-4.
VIAUD, V. - ANGERS, D.A. - WALTER, C. 2010. Towards landscape-scale modeling of soil organic matter dynamics in agroecosystems. In Soil Science Society of America Journal, vol. 74, 2010, no. 6, pp. 1847-1860. DOI: $10.2136 /$ sssaj2009.0412

VAN WESEMAEL, B. - PAUSTIAN, K. - MEERSMANS, J. - GOIDTS, E. - BARANČÍKOVÁ, G. - EASTER, M. 2010. Agricultural management explains historic changes in regional soil carbon stocks. In PNAS, vol. 107, 2010, pp. 14926-14930.

YOKOZAVA, M. - SHIRATO, Y. - SAKAMOTO, T. YONEMURA, S. - NAKAI, M. - OHKURA, T. 2010. Use of the RothC model to estimate the carbon sequestration potential of organic matter application in Japanese arable soils. In Soil Science and Plant Nutrition, vol. 56, 2010, pp. 168-176. DOI:10.1111/j.1747$0765.2009 .00422 . \mathrm{x}$

XU, X. - LIU, W. - KIELY, G. 2011. Modeling the change in soil organic carbon of grassland in response to climate change: Effects of measures versus modelled carbon pool for inizializing Rothamsted Carbon model. In Agriculture, Ecosystems and Environment, vol. 140, 2011, no. 3-4, pp. 372-381.

Received: September $28^{\text {th }}, 2012$ 